\title{
Examining the Effects of Unemployment on Economic Growth in Sri Lanka (1991-2017)
}

\author{
S. A. U. Niranjala \\ Department of Social Sciences, Rajarata University of Sri Lanka, PO box 50300, Mihintale, Sri Lanka
}

\begin{abstract}
Economic growth of a country can be considered as a major requirement to reduce unemployment. This paper has investigated the relationship between growth and unemployment for the period of 1991-2017 in Sri Lanka through the implementation of Okun's law, using ARDL Bound test approach. The empirical results confirmed existence of Okun's Law which is negative relationship between unemployment and economic growth in Sri Lanka. Thus, it can be concluded that the lack of economic growth explain the unemployment problem in Sri Lanka
\end{abstract}

Keywords: ARDL Bound test, GDP, Okun's Law, Unemployment

DOI: $10.7176 / \mathrm{JESD} / 10-20-04$

Publication date:October $31^{\text {st }} 2019$

\section{Introduction}

Low unemployment rate and increase of GDP have become the most challenges that threaten the economies of most developed and developing countries. High rates of unemployment which signifies a deficiency in the labour market, a negative influence on individuals, families and the entire economy. On the other hand, there is a widely accepted view in economics that the growth rate of the GDP of an economy leads to increases employment and reduces unemployment. The negative correlation between in unemployment rate and changes in output growth is viewed as one of the most consistent relationship in macroeconomics. This theoretical proposition relating output and unemployment is called "Okun's Law".

In examining unemployment and economic growth nexus around the world, some studies have proved the existent of inverse relationship between economic growth and unemployment (Soylu,2018; Abu, 2016; Abdulkhaliq,2014; Hussain et al, 2010); while some showing a positive relationship (Kreishan ,2017; Sahin et al., 2013). However, very few attempts to test this relationship have been conducted in developing countries.

Considering Sri Lankan economy, GDP growth rate during last period have been reducing erratically with considerable low level of unemployment rate. The unemployment rate in Sri Lanka fluctuated from 4.9 percent to 4.2 to respectively 2010-2017. Despite a slight increases from 2010 to 2012, real GDP growth rate have been continuously decreasing form 5 percent in 2014 to 3.4 percent in 2017 (See table 1). Therefore, the objective of this study is to investigate the relationship between unemployment and economic growth in Sri Lanka. Thus, an investigation of the relationship between unemployment and output will permit analysts to conduct appropriate policies for the Sri Lankan economy.

Table 1: Economic Growth and Unemployment in Sri Lanka 1991-2017

\begin{tabular}{|c|c|c|c|c|c|c|c|c|}
\hline Year & $\begin{array}{l}\text { Unemployment } \\
\text { rate (\% to total } \\
\text { labour force) }\end{array}$ & $\begin{array}{l}\text { GDP } \\
\text { real } \\
\text { growth } \\
\text { rate } \\
(\%) \\
\end{array}$ & Year & $\begin{array}{l}\text { Unemployment } \\
\text { rate ( } \% \text { to total } \\
\text { labour force) }\end{array}$ & $\begin{array}{l}\text { GDP } \\
\text { real } \\
\text { growth } \\
\text { rate } \\
(\%) \\
\end{array}$ & Year & $\begin{array}{l}\text { Unemployment } \\
\text { rate ( } \% \text { to total } \\
\text { labour force) }\end{array}$ & $\begin{array}{l}\text { GDP } \\
\text { real } \\
\text { growth } \\
\text { rate } \\
(\%) \\
\end{array}$ \\
\hline 1991 & 14.7 & 4.6 & 2000 & 7.6 & 6.0 & 2009 & 5.9 & 3.5 \\
\hline 1992 & 14.6 & 4.3 & 2001 & 7.9 & -1.5 & 2010 & 4.9 & 8.0 \\
\hline 1993 & 13.8 & 6.9 & 2002 & 8.8 & 4.0 & 2011 & 4.2 & 8.4 \\
\hline 1994 & 13.1 & 5.6 & 2003 & 8.4 & 5.9 & 2012 & 4.0 & 9.1 \\
\hline 1995 & 12.3 & 5.5 & 2004 & 8.3 & 5.4 & 2013 & 4.4 & 3.4 \\
\hline 1996 & 11.3 & 3.8 & 2005 & 7.7 & 6.2 & 2014 & 4.3 & 5.0 \\
\hline 1997 & 10.5 & 6.3 & 2006 & 6.5 & 7.7 & 2015 & 4.7 & 5.0 \\
\hline 1998 & 9.2 & 4.7 & 2007 & 6.0 & 6.8 & 2016 & 4.4 & 4.5 \\
\hline 1999 & 8.9 & 4.3 & 2008 & 5.4 & 6.0 & 2017 & 4.2 & 3.4 \\
\hline
\end{tabular}

Source: Department of Census and Statistics, Sri Lanka

\section{Theoretical background and Literature Review}

\subsection{OKUN'S LAW}

The well-known economist Arthur Okun, was the first who started investigates the statistical relationship between a country's unemployment rate in relation to the growth rate in the 1960s. Okun's law predicts a negative relationship between the rate of change in the unemployment rate and the rate of change in output. In his original paper published in 1962 Okun found that every lpercentage point reduction was associated with additional output 
growth of 3 percentage point in the US economy. However, the negative correlation between in unemployment rate and changes in output growth is viewed as one of the most consistent relationship in macroeconomics (Adachi, 2007). Theoretically, Okun investigated that the increased workforce must produce more goods and services. Further, Okun found that the unemployment rate declined in the years when the real growth rate was high, whereas the unemployment rate increased in the years when the real growth rate remained low or even negative. Another version of Okun's Law displays the relationship between unemployment and GDP, whereby the percentage increase of $1 \%$ in unemployment, causes a $2 \%$ fall in GDP. The Okun's Law is not a very exact determiner, however the empirical evidence still holds on its benefits(Misini \& Badivuku-pantina, 2017).

\subsection{Literature Review}

A number of studies have followed investigating empirically the relationship between output (GDP) and unemployment (Soylu, 2018; Abu, 2016; Abdul-khaliq, 2014; Sahin et al., 2013 Hussain et al, 2010). These studies have discovered the validity of the relation between output and unemployment rate and reported mixed results.

Hussain et al. (2010) examined the relationship between growth and unemployment, using time series data for Pakistan from 1972 to 2006. Johanson Cointegration test and Vector Error Correction Model (VECM) were employed. The results indicated that there is short and long run causal relation between growth and unemployment. Kitov (2011) investigated the relationship between employment and real GDP per capita in his study of the US, France, UK, Australia, Canada and Spain economies. As a result of this study, Kitov (2011) has found that high unemployment rates are affected by low growth rates.

Furthermore, other studies observed a reversed relationship between unemployment and output. Sahin et al. (2013) investigated that the nature of the output-employment relationship by using the Turkish quarterly data for the period 1988-2008, employed unit roots, cointegration properties and the error correction models. Research findings reveals that no long-run relationship between aggregate output and total employment. Mosikari (2013) investigated the effect of unemployment on gross domestic product in South Africa in based on annual time series the period for 1980-2011 and it was found that there is no causality found between unemployment rate and GDP growth. Harris and Silverstone (2001) have questioned unemployment and output levels relationship using seven OECD countries but empirical evidences confirmed that there is no long-run relationship between two variables. Seth et al. (2018) also concluded that there is no long run relationship between unemployment rate and economic growth in Nigeria covering the period of 1986 to 2015 using the ARDL Bound Testing model. Alhdiy et al., (2015) indicated that there were no cointegration relationship between the variables of unemployment and GDP, specifically implying there is no long-term relationship between the variables in Egypt between 2006 Q1 - 2013 Q2

Particular studies have directly tested Okun's law and reported mixed results because they used different datasets, different techniques, various time periods, and different countries. Certain studies have determined that output growth has a negative effect on unemployment rate.

Kukaj (2018) investigated the relationship between unemployment and GDP growth in 7 countries of Western Balkan; precisely it studies the relationship of GDP-growth as a dependent variable with unemployment. Foreign direct investment, and remittances as independent variables. results is it found out that there exists a trade-off between unemployment and economic growth in Western Balkan countries, meanwhile, the model suggests that an increase by one percent point of unemployment will reduce GDP-growth by 0.5 percent points. Soylu (2018) investigated the relation between economic growth and unemployment in Eastern European Countries for the period of 1992-2014, using Panel Unit Root, Pooled Panel OLS and Panel Johansen Co-integration tests. The results showed that the unemployment affected positively by economic growth, in other words $1 \%$ rise in GDP will fall the unemployment rate by $0.08 \%$. Abu (2016) employs the autoregressive distributed lag (ARDL) bounds testing technique to examine whether Okun's law exists in Nigeria during 1970-2014. The results demonstrate that in Nigeria, in the long term, unemployment has a negative and significant effect on economic growth. Ruxandra (2015) also examined the relationship between economic growth and unemployment for the post-2007 period. It has been determined that Okun's Law is valid for the Romanian economy. Abdul- khaliq (2014) has explored the relationship between unemployment and GDP growth in 9 Arab Countries, from 1994 to 2010, found that economic growth has negative and significant effect upon the unemployment rate it means that $1 \%$ increase in economic Growth will decrease the unemployment rate by $0.16 \%$.

However, some studies refuted the existence of Okun's law. Kreishan (2017) investigates the relationship between unemployment and economic growth in Jordan through the implementation of Okun's law, using annual data covering the period 1970-2008, ADF, Cointergration test and Simple regression are used to test the relation between unemployment and economic growth and to obtain estimates for Okun's coefficient. The empirical results reveal that Okun's law cannot be confirmed for Jordan. Fatai and Bankole (2013) have studied Okun's Law for the Nigerian economy within the period of 1980-2008. The results show that the Okun's Law is not valid for the Nigerian economy. Kreishan (2011) reviewed the relationship between economic growth and unemployment for the Jordanian economy. Kreishan (2011) estimated the Okun's coefficient for the period 1970-2008. As a result of the analysis, it is stated that the Okun's Law is not valid for the Jordian economy. 


\section{Methodology}

\subsection{Data Collection}

The study was entirely based on time series secondary data for the period covering from 1991 to 2017 . The data were obtained from the Central Bank of Sri Lanka and Census and Statistical Department in Sri Lanka. The two economic variables included in this study are GDP (Sri Lanka's Gross Domestic Product) growth rate and Unemployment rate. The dependent variable was the Gross Domestic Product and unemployment rate was the independent variable. All of the variables have been transformed into differentiated forms as logarithms are a much more useful way to measure economic data and the resulting variables are denoted as LnGDP, LnUNEM.

\subsection{Model description:}

According to the original form of Okun's law, there exists a negative relation between the growth rate of real GDP and the change in unemployment rate. Using the knowledge gained from the studied literature, a model was developed based on the model developed by (Mohseni \& Jouzaryan, 2016). The model used to estimate the effect of unemployment on Sri Lankan economy from 1991 to 2017 in framework of this function and the proposed model (Equation 1):

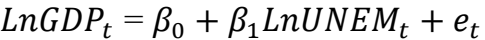

Where GDP shows Gross Domestic Production, UNEM denotes unemployment rate and $e_{t}$ shows disturbance term. $\alpha$, and $\beta 1$ parameters should also be estimated. Eviews version 6.0 were used to estimate the model.

Equation (1) is re-written following the Autoregressive Distributed Lag (ARDL) bound test suggested by (Wong, 2018) Pesaran et al. (2001). The reason was due to evidences that the ARDL approach accommodate variables of different order of integration with the exception of variables which integration are higher than one. Additionally, the ARDL approach accommodates both the short run dynamics with the long-run equilibrium without losing long-run information, hence equation 02 .

$\Delta \operatorname{LnGDP} P_{t}=-\propto-\sum_{m=1}^{\rho} \varphi_{m} \Delta \operatorname{LnGDP} P_{t-m}-\sum_{n=1}^{\rho} \beta_{n} \operatorname{LnUNEM} M_{t-n}+\Psi_{1} \operatorname{LnGDP} P_{t-1}+\Psi_{2} \operatorname{LnUNEM} M_{t-1}+$ $E C M_{t-1}+\varepsilon_{t} \ldots(02)$

Where: $\Delta$ is the first difference operator, $\varphi \mathrm{m}$ and $\beta \mathrm{n}$ are the short-run dynamic coefficients, and $\alpha$ is the drift, while $\psi 1$ and 2 are the long-run multipliers, ECM is an error correction model, $\varepsilon$ t represent white noise errors, $\rho$ is the lag length which will be chosen optimally by the model using Schwarz information criterion (SIC) and Akaike Information Criterion (AIC).

In first step, null hypothesis of no cointegration that is $H_{0}: \Psi_{1}=\Psi_{2}=0$ is tested against the alternative hypothesis of co-integration is $H_{1}: \Psi_{1} \neq \Psi_{2} \neq 0$.Calculated F-statistic values are compared with critical bounds values provided by Pesaran et al (2001) for determination of the long run relationship. There are two sets of critical values: the lower bound which assumes I (0) and upper bounds assuming I (1). If the calculated value of Fstatistics are greater than upper-critical bound values, we reject the null hypothesis of no cointegration in favour of alternative hypotheses of cointegration. If the calculated value of the F - statistic is smaller than the lower critical bound value than we accept the null hypothesis of no cointegration. If values of the calculated F - statistic lies within upper and lower critical bound values than we neither reject nor accept the null hypothesis.

\subsection{Estimation Methods}

Since time series variables were used in the model, it is necessary to examine and confirm stationarity of the variables in order to avoid spurious regression in model estimation. In order to obtain reliable regression results, we first need to make sure that our model could not be subject to "spurious regression" (Gujarati, 1995). Therefore, we first test the nature of the time series to determine whether they are stationary or non-stationary. Unit root tests were used to determine whether the time series data were stationary. When time series data is non stationary and used for analysis it may give spurious results because estimates obtained from such data will possess non constant mean and variance. In this regard Augmented Dickey Fuller (ADF) and PP test were used to test for unit roots. First, the Dickey-Fuller test was applied to both variables to detect if these variables were stationary or nonstationary. Both variables proved to be non-stationary; regression tests were applied to the first differences.

In the following, Auto-Regressive Distributed Lags (ARDL) Bounds test was used to find cointegration between two variables. The ARDL bounds testing approach to cointegration proposed by Pesaran et al. (2001) does not require a unique order of integration for estimation of cointegration. Long run relationship is investigated using extreme values of bounds test, whereas, short and long run elasticity's are estimated using ARDL model. Therefore, ARDL model was used to assess long-term relationships and short-term dynamics between unemployment and economic growth in Sri Lanka. CUSUM and CUSUM OF SQVARES tests were examined and analyzed for find the stability.

\section{Results and Discussion}

Table 2 shows the summary of statistical data of economic growth rate and unemployment rate in Sri Lanka 
between the periods from 1991 to 2017.

Table 02: Descriptive Statistics

\begin{tabular}{lll}
\hline & Economic growth rate & Unemployment rate \\
\hline Mean & 5.2889 & 8.0259 \\
Std. Error of Mean & .39496 & .66228 \\
Median & 5.4000 & 7.7000 \\
Std. Deviation & 2.05227 & 3.44133 \\
Skewness & -1.013 & .619 \\
Std. Error of Skewness & .448 & .448 \\
Kurtosis & 3.660 & -.737 \\
Std. Error of Kurtosis & .872 & .872 \\
Minimum & -1.50 & 4.00 \\
Maximum & 9.10 & 14.70 \\
Sum & 142.80 & 216.70 \\
\hline
\end{tabular}

Source: Researcher calculation

Table 2 presented that the Sri Lankan economy was growing on the average of 5.3\% between the years 1991 - 2017. The maximum economic growth rate in Sri Lanka was 9.1\% which occur in year 2012 and the minimum growth rate of the economy is $-1.5 \%$ which occur in year 2001 between the periods of 1991-2017. In the same period, average unemployment rate is at 8\% in Sri Lanka. The maximum unemployment rate from 1990-2018 in Sri Lanka was 14.7\% which occur in year 1991 while the minimum unemployment rate stood at $4 \%$ in year 2012.

Table 03: Unit Root Test

\begin{tabular}{|c|c|c|c|c|c|}
\hline \multirow[t]{3}{*}{ Variables } & \multicolumn{5}{|c|}{ Augmented Dickey- Fuller (ADF) test } \\
\hline & \multicolumn{2}{|c|}{ level } & \multicolumn{2}{|l|}{ 1st Diff. } & \multirow[t]{2}{*}{ Order } \\
\hline & Intercept & Trend and Intercept & Intercept & $\begin{array}{l}\text { Trend } \\
\text { Intercept }\end{array}$ & \\
\hline LnGDP & $-4.219935 * * *$ & $-4.050589 * *$ & - & - & $1(0)$ \\
\hline LnUNEM & -0.987566 & -1.962533 & $-4.623200 * * *$ & $-4.632850 * * *$ & $1(1)$ \\
\hline \multicolumn{6}{|c|}{ Phillip- Perron (PP) test } \\
\hline LnGDP & $-4.221776 * * *$ & $-4.050262 * *$ & - & - & $1(0)$ \\
\hline LnUNEM & -0.987427 & -2.120986 & $-4.624224 * * *$ & $-4.623691 * * *$ & $1(1)$ \\
\hline
\end{tabular}

Source : Researcher calculation

The unit root estimation shows (see table 03) that the growth rate of GDP is stationary at level for both the Augmented Dickey-Fuller (ADF) test and Philip-Perron (PP), however unemployment variables has unit root problems at $\mathrm{I}(0)$ and is made stationary at first difference for both the ADF and PP. Since the order of integration variables is zero and one, cointegration Johansen method could not be used. Therefore, the ARDL bound test can be applied in testing for the short and long run dynamism on the two variables.

Table 04: Bound Test Critical Value

\begin{tabular}{lll}
\hline Critical Value & Lower Bound Value I(0) & Upper Bound Value I(1) \\
\hline $1 \%$ & 6.44 & 6.44 \\
$5 \%$ & 4.6 & 4.6 \\
$10 \%$ & 3.8 & 3.8
\end{tabular}

Calculated F- Statistics $=8.517619, \mathrm{~K}=0$

Source: Researcher calculation

Table 04 shows that critical values of bound test. Calculated F - statistic (8.517619) is greater than the critical value at $1 \%, 5 \%$ and $10 \%$ for the upper bound $\mathrm{I}(1)$, then it is concluded that there is cointegration. This implies that there is a long-run relationship between economic growth rate and unemployment rate in Sri Lanka

Table 05: Model coefficients in long term

\begin{tabular}{llll}
\hline Regressor & Coefficient & Standard error & t- ratio(Prob.) \\
\hline LnUNEM & -1.172657 & 0.594809 & $-1.971485(0.0627)$ \\
C & 4.920535 & 1.733107 & $2.839140(0.0101)$ \\
TREND & -0.062852 & 0.031827 & $-1.974828(0.0623)$ \\
F-stat 1.358337(0.284090) & & & \\
\hline
\end{tabular}

Source: Researcher Calculation

According to the long term model coefficiets (Table 05), the overall results suggested that unemployment had a negative and significant effect on gross national product. The results also showed that $1 \%$ increase in unemployment reduced gross national product up to $1.17 \%$ in long term.

Cointegration between a set of economic variables is a basic rule for using error correction model, which is mainly used to associate short-term fluctuations to relevant long-term values. 
Table 06: Result of Error Correction Method (ECM)

\begin{tabular}{llll}
\hline Regressor & Coefficient & Standard error & t- ratio(Prob.) \\
\hline DLnGDP (-1) & 0.088159 & 0.272353 & $0.323695(0.7499)$ \\
DLnUNME (-1) & 0.568216 & 1.092002 & $0.520343(0.6092)$ \\
C & 0.039252 & 0.091436 & $0.429286(0.6728)$ \\
ECM(-1) & -0.917921 & 0.404607 & $-2.268675(0.0358)$ \\
\hline F-stat & $3.570460(0.034735)$ & & \\
R- squared & 0.373071 & & \\
Durbin - Watson stat & 2.024697 & & \\
\hline
\end{tabular}

Source: Researcher calculation

The Error Correction Term [ECT(-1)] which assesses the speed of adjustment between the short-run disequilibrium (actual) and the long-run equilibrium (expected) has the correct sign and is statistically significant at $5 \%$ (see table 06). The estimated coefficient, it will take the speed of $91 \%$ in the case of disequilibrium in the short-run to be corrected in the long-run if the right policy measures are put in place.

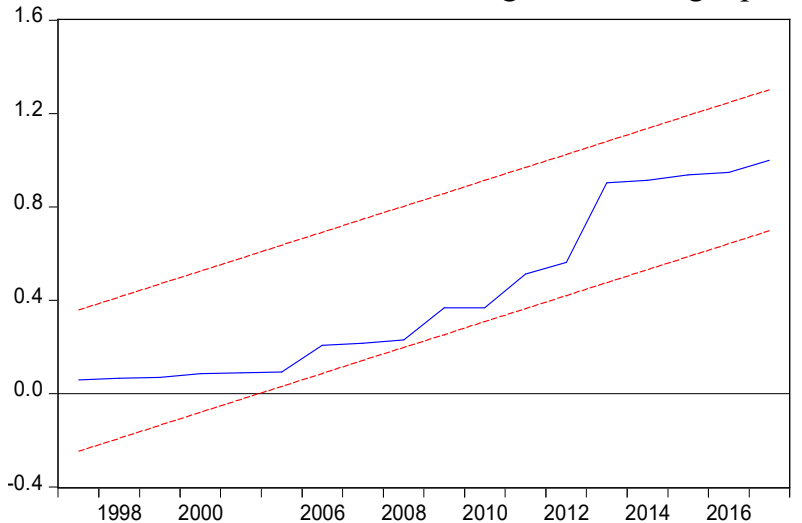

_ CUSUM of Squares ---- 5\% Significance

Fig1. Cumulative Sum of Recursive Residuals (CUSUM)

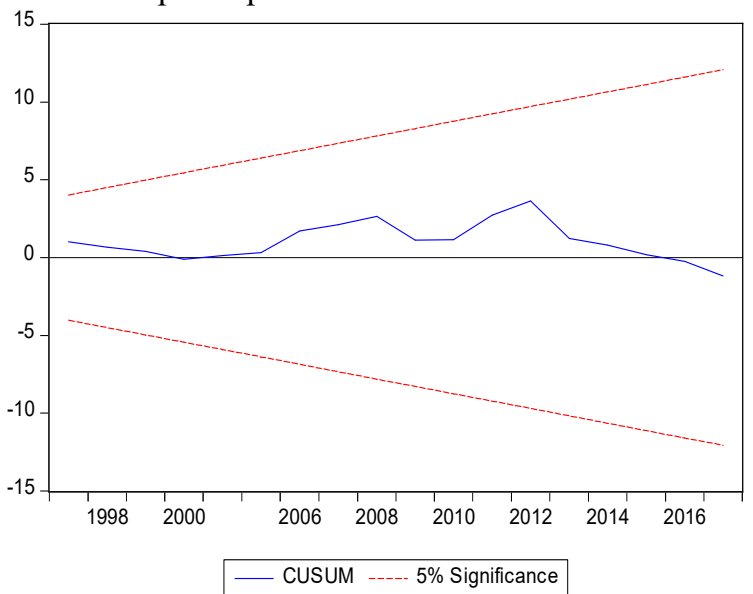

Fig 2. Cumulative Sum of Squares of Recursive Residuals and (CUSUMSQ)

Stability of model parameters was examined using statistics of Cumulative Sum of Recursive Residuals (CUSUM) and Cumulative Sum of Squares of Recursive Residuals (CUSUMSQ). If the statistics were between boundary lines drawn as two separate lines, the null hypothesis claiming stability of parameters would not be rejected. The results of these tests for model estimation are given in Figure 1 and Figure 2. Therefore, model parameters were stable within $5 \%$ critical bounds.

\section{Conclusion and recommendations}

Economic growth of a country can be considered as a major source to reduce unemployment. This paper has investigated the relationship between growth and unemployment for the period of 1991-2016 in Sri Lanka through the implementation of Okun's law. Time series techniques are used to test the relation between unemployment and economic growth and to obtain estimates for Okun's coefficient. This study used Augmented Dickey-Fuller (ADF) for unit root, ARDL Bounds testing approach.

The findings showed that there is long- run relationship between unemployment rate and economic growth in Sri Lanka. The estimated results of the study conformed existence of stable, long run negative effect, whereas, in short run no relationship is observed. A one percent increase in unemployment is associated with reduction in the growth level by 1.17 percent in the long run. The ECM indicates high speed of adjustment of short run fluctuation as 91 percent short disequilibrium adjusts in a year.

Continued economic growth of a country is the fundamental requirement to reduce unemployment. Macroeconomic stability, investment oriented policies and political stability will be the major source to attain attractive growth rate of a country. It is needed to establish proper long-term industrial policies specially labour intensive policies for Sri Lanka to reduce unemployment. High unemployment rate can be seen in rural areas in Sri Lanka. Therefore, it is needed to establishment of industrial zones in rural areas, improve the human capital and develop infrastructure facilities to reduce unemployment.

\section{References}

Abdul-khaliq, S., Soufan, T., Shihab, R.A. (2014). "The Relationship between Unemployment and Economic Growth Rate in Arab Country", Journal of Economics and Sustainable Development, 5(9), 56-60.

Abu, N. (2016). “Does Okun's Law Exist in Nigeria ? Evidence from the ARDL Bounds Testing Approach”, 131- 
144. Retrieved from https://doi.org/10.5709/ce.1897-9254.232

Adachi, H. (2007). "Economic Growth and Unemployment -Theoretical Foundations of Okun 's Law"-, 1-13.

Alhdiy, F. M., Johari, F., Daud, S. N. M., Rahman, A. A. (2015). "Short and Long Term Relationship between Economic Growth and Unemployment in Egypt: An Empirical Analysis", 6(4), 454-462. Retrieved from https://doi.org/10.5901/mjss.2015.v6n4s3, p454

Ceylan, S., \& Sahin, B. Y. (2010). "Asymmetry in the Erlationship between Unemployment and Economic Growth". Dogus University Journal, 11(2), 157-165. Retrieved from http://journal.dogus.edu.tr/index.php/duj/article/view/15.

Fatai, B. O., \& Bankole, A. (2013). "Empirical test of Okun's Law in Nigeria”. International Journal of Economic Practices and Theories, 3(3), 227-231. Retrieved from http://ijept.org/index.php/ijept/article/view/Empirical_Test_of_Okun_Law_in_Nigeria.

Gujarati, D., 1995. Basic Econometrics. 3rd Edn., McGraw-Hill, USA., ISBN: $975 \overline{7} 860557$, pp: 838.

Harris, R., \& Silverstone, B. (2001). "Testing for asymmetry in Okun's law: A cross-country comparison". Economics Bulletin, 5(2), 1-13. Retrieved from http:/www.economicsbulletin.com/2001/volume5/EB01E00001A.pdf.

Hussain, T., Siddiqi, M. W., \& Iqbal, A. (2010). "A Coherent Relationship between Economic Growth and Unemployment : An Empirical Evidence from Pakistan”, International Journal of Human and Social Sciences, 4(3), 288-295.

Kitov, I. (2011). “Okun's law revisited: Is there structural unemployment in developed countries?”. Retrieved from http://dx.doi.org/10.2139/ssrn.1883003

Kreishan, F. M. (2017). "Economic Growth and Unemployment: An Empirical Analysis", Journal of Social Sciences, 7 (2), 228-231. Retrieved from https://doi.org/10.3844/jssp.2011.228.231

Kukaj, D. (2018). "Impact of Unemployment on Economic Growth : Evidence from Western Balkans", European Journal of Marketing and Economics 8659, 1(1), 10-18.

Misini, S., \& Badivuku-pantina, M. (2017). "The effect of Economic Growth in relation to Unemployment", Journal of Economics and Economic Education Research, 18(2), 1-9.

Mosikari, T. J. (2013). "The Effect of Unemployment Rate on Gross Domestic Product : Case of South Africa”, Mediterranean Journal of Social Sciences, 4(6), 429-434. Retrieved from https://doi.org/10.5901/mjss.2013.v4n6p429

Okun, A.M. (1962), "Potential GNP: Its Measurement and Significance", American Statistical Association, Proceedings of the Business and Economics Section, 98-103.

Pesaran, M. H., Shin, Y., and Smith, R. J. (2001). "Bound Testing approaches to the analysis of level relationships". Journal of Applied Econometrics, Vol.16, pp. 289-326.

Şahin, A. (2013). "Output-Employment Relationship across Sectors : Output-Employment Relationship across Sectors : A Long- versus Short-Run Perspective", (7599).

Seth, A., John, M.A., Dalhatu, A.Y. (2018). "The Impact of Unemployment on Economic Growth in Nigeria : An Application of Autoregressive Distributed Lag (ARDL) Bound Testing", Sumerianz Journal of Business Management and Marketing, 1(2), 37-46.

Soylu, Ö. B. (2018). "Economic growth and unemployment issue: Panel data analysis in Eastern European Countries", Journal of International Studies,11(1), 93-107. Retrieved from https://doi.org/10.14254/2071$8330.2018 / 11-1 / 7$

Ruxandra, P. (2015). “The Specifics of Okun'S Law in the Romanian Economy Between 2007 And 2013”. AnnalsEconomy Series, 1, 50-53. 